\title{
Students' Perceptions and Attitudes toward Sustainable Tourism Development in Albania
}

\author{
Dr. Mirjam Dibra \\ University of Shkodra "Luigj Gurakuqi", \\ Faculty of Economics, Tourism Department, Albania \\ E-mail: dibramirjam@yahoo.com \\ Ted Oelfke, CFE, CHE, FMP, \\ Sandhills Community College of North Carolina, USA, \\ Chair of Hospitality and Culinary Arts, \\ E-mail: oelfket@sandhills.edu
}

\section{Doi:10.5901/mjss.2013.v4n10p706}

\begin{abstract}
Nowadays, tourism in Albania has been considered a new phenomenon. Its growth needs to be managed in order to provide a successful future of tourism and an increase of the potential contribution of tourism for the country's sustainable development. This requires tourism to be developed in a sustainable manner. This study focuses on the perceptions towards sustainable tourism development in Albania. The purpose of this study is to analyze students' perceptions towards tourism development in Albania in order to understand the nature of tourism impacts in the three dimensions of its development. To obtain necessary data, a structured questionnaire was delivered on-line to all students of the MA program on "Sustainable Tourism Management" at University of Shkodra "Luigj Gurakuqi". Liker-scale was used to measure the perceptions of the students on tourism development in Albania. The findings from descriptive data analysis provide evidence on the costs and benefits of current development of tourism and also provide students' suggestions on a sustainable future of tourism in this country. In general, tourism students' knowledge and perceptions towards sustainable tourism development in Albania have not been analyzed up to now. Through this study we hope to contribute to filling this gap, by offering the first empirical study that measures students' knowledge towards sustainable tourism development and their suggestions to promote it. Findings of this study are an important contribution for setting up the strategy of sustainable tourism development in Albania.
\end{abstract}

Keywords: Student's perception, sustainable tourism development, Albania

\section{Introduction}

It is recognized that education is the most efficient way to change people thinking to a particular problem and to make the desired change in their attitude.

Nowadays, sustainable development (SD) is a core issue implicating every step of development. In support of SD, it is internationally accepted that education is a vital tool, since achieving SD is essentially a process of learning (UNESCO, 2002). Basically, the SD is a way of thinking about how we organize our lives and work using limited natural resources in order to satisfy needs not only of our generation, but also of future generations. So, SD requires a change in the mental models which structure our thinking and inform our decisions and actions for more responsibility (UNESCO, 2005; 2009). This is reflected in international, national, and regional policies, strategies, and programs on development. On the other hand, there is still no roadmap or ideal strategy which would guarantee achieving the best possible state of sustainability (Tilbury, 2011). The concept of sustainability can be operationalized in a wide variety of ways and the appropriate application of actions for SD depends on the country. Therefore, it is necessary to learn the way towards more sustainable futures (Tilbury, 2011).The general success for any SD policy, strategy, and program depends on peoples' involvement, acceptance of responsibility and common acting to face the challenges of SD. To ensure these, relevant information needs to be provided for people in order that SD concept to be understood and also applied; moreover their abilities and motivation need to be formed to sustain this course. Through education for SD, it is possible not only to understand SD concept, but also to promote SD and to improve the capability of people to address the issues SD with responsibility. 
UNESCO (2009) has defined Higher Education Institutions as a potential driving force of change towards sustainability. In this way, the great challenge of the 21st century for institutions of higher education is to train future professional students capable of acting in favor of SD (Junyent, 2007).

This challenge is even greater in higher education institutions of tourism because the importance of sustainability is particularly a fundamental necessity in tourism (Weawer, 2006). On the one hand, tourism is highly dependent on natural resources, which are often scarce and fragile, and is developed in sensitive socio-cultural environments (Boyle, 2012). On the other hand, tourism is estimated as an important contributor to the SD of a country with potential tourist sources. Recently tourism has been seriously considered in the national SD strategies of many countries. Tourism development (ST) appears to be a very attractive method of achieving the economic growth of a country at a time when all indications are that tourism demand will continue growing in the future years (UNWTO, 2011, 2012). It has the potential to improve the national balance of payments through the new currency introduced by international tourists, to stimulate investment, to diversify the economy, to generate a larger and faster growth in employment than the same investment in another economic activity, to contribute to improving the quality of life, to provide a new ready market for local products and son on (Middelton \& Hawkins, 1998; Sharpley, 2004; Swarbrooke, 2002). In this way tourism serves as agent of development in many countries, but the rapid unlimited growth and non-right management of the tourism puts pressure on the environment of traditional and new tourist destinations, making that an agent of harmful change (Middelton \& Hawkins, 1998).

Given these considerations, the tourism industry is confronted with serious and difficult choices about its future. This happens because the decisions made now will affect the lifestyles and economic opportunity of residents in tourism destinations for decades. Many of these decisions are irreversible because once communities lose the character that makes them distinctive and attractive to nonresidents, they have lost their ability to compete for tourist-based income in an increasingly global and competitive marketplace (Dibra \& Dhora, 2012). Therefore, it is necessary to plan and develop tourism to be environmentally and social-economically sustainable. Establishing of a suitable balance between these three dimensions is exactly a guarantee for long-term sustainability in tourism (UNEP \& UNWTO, 2005). In the efforts to achieve this, on the one hand, it should maintain a high level of tourist satisfaction, ensure strong awareness about sustainability issues and promote ST practices amongst them, and on other hand, it should provide (UNEP \& UNWTO, 2005) the following:

- Economic sustainability, which means realization of the viable, long-term economic operations, providing socio-economic benefits that are fairly distributed to all stakeholders, including stable employment and income-earning opportunities and social services to host communities, contributing to poverty mitigation;

- Social-cultural sustainability, which means respect of the socio-cultural authenticity of host communities, protection and preservation of their material and living cultural heritage and traditional values, contribution to inter-cultural understanding and tolerance, and generation of a better quality of life;

- Environmental sustainability, which means optimal use of environmental resources that represent a key element in tourism development, maintaining vital ecological processes and helping to conserve natural heritage and biodiversity.

Within this context, it is clear that abilities and competences for management with responsibility of tourism destinations and businesses for the sustainable future need to be developed for tourism management students who are the future industry leaders and managers. For this, ST in higher education institution is learnt not only to gain knowledge about theories related to sustainable tourism but it also calls for students' changing mindsets and their active commitment in matters relating to more ST futures (Dibra \& Oelfke, 2011).

Many international network of tourism educators and industry practitioners as The Tourism Education Futures Initiative (TEFI), International Society of Travel and Tourism Educators (ISTTE), the BEST Education Network, etc have also recognized sustainability as an important value to be communicated through tourism education and have published some studies on teaching ST. However, there are no studies to assess what tourism students actually feel about sustainability in tourism development of a country.

The authors of this study examine and analyze the perceptions of tourism management students toward the importance of tourism development in a sustainable manner, current impacts of tourism development in their country, and also examine the most important suggestions of the students for further development of tourism in a sustainable manner in their country.

\section{Scope and Significance of the Study}


The space of this study lies in Albania, where tourism is considered as a new phenomenon and where the growth of tourism must be well managed for the sustainable future of tourism in Albania. There is a rich, natural and historicalcultural heritage as basic resource supporting tourism in Albania. The existence of many unique tourist resources create opportunities to develop cultural, coastal, mountainous (green and white), adventure tourism, etc in Albania. Only after the '90-ties, with the opening of Albania to the world, tourism has been made part of the country's development policies and strategies of the government. These policies have determined tourism as a priority industry for the rapid and SD of the country (MTKRS, 2003, 2007). In this way, tourism especially, is expected to play a leading role in achieving a balance between the social-economic development and environmental protection in Albania. However, the success of these policies is often evaluated primarily through the ability to increase tourist numbers. In fact, according to INSTAT (2012), the number of international visitors until 2012 increased 11.9 times more than in 1995. This is not enough if we seek to develop ST. As tourism continues to grow in Albania, the tourism industry faces serious and difficult choices about its future. In ensuring that tourism development is going in the right direction, a number of political actions have been determined. However, governmental commitment to sustainable tourism development (STD) in Albania has not always submitted into practice, besides, the current practice of tourism businesses in Albania have not helped STD (Dibra \& Oelfke, 2011). The growing attention to tourism development in Albania has been driven by the short-time economic benefits that the industry can bring. However, the decisions made will affect the social-economic aspects of the life of residents for the present and the future. Based on the appealing attractions of Albania to tourism market, to differentiate itself regionally and internationally, many of these decisions, which will lead to the loss of its character and make it distinctive and attractive to this market, may be irrevocable. Consequently, this will lead to the loss of competitive opportunities of Albania for income from tourism and only low prices can keep it in the market. If we want to avoid the serious damage of the resources on which tourism depends, then this growth must be well managed for sustainable future of tourism in Albania. In the management of tourism towards sustainability, the higher education institutions of tourism in Albania should be a potential driving force because tourism students will be future manager of tourism.

For this, the authors of the research want to see how students of tourism management perceive the importance of tourism development in a sustainable manner in Albania, how they estimate the impacts of actual tourism development in their country and how the students are future-oriented in finding innovative and effective solutions to issues affecting the sustainable future of tourism in Albania. The research was strictly focused on all students of MA program on "Sustainable Tourism Management" (STM) at the University of Shkodra "Luigj Gurakuqi" in Albania. This is because of the fact that the students involved in this study are longer exposed to the curricula of STD, and are more familiar with this subject through the analysis of different case studies related to the sustainable tourism development.

This study is a continuation of the work of its authors as educators of the 21st century who are involved in the global sustainability course through their ongoing discussions with the purpose of promoting the STD and improving the role of High Education Institutions in this respect. Specifically, this study enables the researchers to shed light on tourism students' feedback on actual tourism development in Albania and on their perspectives to address the issues of STD in Albania with responsibility. The findings of this study provide evidence to the costs and benefits of current development of tourism in Albania, and also present suggestions on a sustainable future of tourism in this country. Therefore, information from this study can assist Albanian politician makers in their work to prepare the long-term strategy for sustainable tourism development in Albania. Until then, the knowledge and perceptions of tourism students towards sustainable tourism development have not been studied. With this study we hope to contribute to filling this gap by offering a first empirical research that measures tourism students' knowledge and perspectives to promote and implement sustainability practices in tourism.

\section{Methodology}

The research scheme supposes that the perceptions and attitudes of students of MA program on STM about the impact of actual tourism development determine solutions offered by them to tourism development for sustainable future. The type of design used was exploratory. A quantitative research method was used to cover the objectives and contents of this study. A questionnaire was designed as an instrument to collect data because it is estimated as the most popular research method for measuring attitudes and providing numerous, organized and reliable data. The literature was explored to develop the items of questionnaire. The questionnaire was designed as a structured one, with closed questions which facilitate management, tabulation, data analysis, the response of the respondents and makes these responses reliable. The questionnaire comprised four sections. The first section was about the importance of sustainable tourism development in Albania. Construction of the second section of the questionnaire was based on the purpose of 
sustainable tourism development to maximize the positive impacts and minimize the negative impacts of tourism development. For this, the second section consisted of 43 attitudinal statements concerning the economic, social-cultural and environmental impacts of tourism development in Albania. All statements were measured using on five-point Likert scale, ranging from 'strongly agree' (1) to 'strongly disagree' (5). The third section required from students to rank suggestions in the order of importance for the further development of tourism for sustainable future. The last section was the demographic profile of student respondents.

The population of interest for this study was all students attending the summer term in MA program of STM at the University of Shkodra. The total number was 54 students. The major premise from which researchers started this study was that the students of this study program already have theoretical and practical knowledge on sustainable tourism development. they they have accumulated it over the years of study in this study program, and they have knowledge about tourism development in Albania as residents and also as future managers of tourism in Albania.

A research software tool, Qualtrics, as a fast and easy method to deliver the questionnaire, to collect data on-line, to keep anonymity, to encourage response to sensitive issues, and to process the data collected was used. The survey was conducted in May 2013 for 3 days. A total of 50 students completed the questionnaires, accounting to a response rate of $92.59 \%$.

Descriptive statistical methods were employed to analyze the responses collected in the research. To interpret these results, the five level of Likert scales were differed by 0.80 point as follows: Class interval= (Maximum score Minimum score $) /$ Class number $=(5-1) / 5=0.80$. So, the applied scales in the study to interpret the calculated mean scores of Likert scales are: $1-1.80=$ strongly agree $(\mathrm{SA}) ; 1.81-2.60=$ agree $(\mathrm{A}) ; 2.61-3.40=$ neutral $(\mathrm{N}) ; 3.41-4.20=$ disagree (D); $4.21-5.00=$ strongly disagree (SD). The calculated mean scores were ranked from the lowest mean to highest one in the respective tables.

\section{Findings and Discussion}

Profile of the respondents: $52 \%$ of the students responded the survey at the end of the first year and $48 \%$ of them at the end of the second year of MA study program on Sustainable Tourism Management. The majority of respondents (74\%) were female. The main age group was 21-25 years old, representing $90 \%$ of the respondents; the others were $26-30$ years old. With regard to employment, only $36 \%$ of respondents stated that they do jobs related to tourism, while $16 \%$ of respondents stated they are currently employed in different sectors of industry other than tourism and the rest weren't employed. Of 50 survey students, $94 \%$ were Albanian and $6 \%$ were Montenegrin. The authors believe that the main reason for the respondents' answers about their level of knowledge on tourism development in Albania may be the country of residence. $84 \%$ of them stated that they had a lot of knowledge, and $16 \%$ of them stated that they had average knowledge about the content of the questionnaire.

Respondents' perceptions towards the importance of sustainable tourism development: All the students surveyed agreed strongly (mean=1.08 and S.Dev. $=0.28$ ) that tourism development in our country guarantees success if it were developed in sustainable manner. They strongly believed (mean=1.53 and S.Dev. $=0.58$ ) that only developed in this manner, can tourism be one of the main ways through which Albania may achieve rapid and sustainable development.

Attitudes towards Perceived Overall Impact of Tourism: In general, students had positive attitudes towards the overall impact of tourism development in Albania (the average value of all means of impact items $=2.18$ ). Moreover, figures revealed by the survey clearly confirmed that the students view more positive aspects than negative ones of tourism development in this country. The average value of all means of positive impact items is 1.99 while that of the negative impact items has the value of 2.401. Regarding their attitude towards three aspects of tourism development, the students showed more favorable attitude to the economic impacts of tourism development (mean=2.10). They felt that tourism industry would play a major economic role in Albania. Following the economic impact of tourism, social-cultural impacts and environmental impacts of tourism are evaluated relatively favorably (respective means 2.24 and 2.44). Analytically, on the one hand, students felt more the positive impacts in economic aspect of tourism development (mean=1.94), on other hand, they believed that the negative impacts of tourism are more present in the environment (mean=2.31), whereas, data on negative social-cultural impacts of tourism development disclosed a conservative stand of students to the influence of tourism in this aspect of development (the respective overall average 2.65).

Table 1: The average value of all means of impact items

\footnotetext{
1 the smaller value of the mean shows a greater approval of impact item
} 


\begin{tabular}{|l|c|c|c|c|c|c|}
\hline Tourism Impacts & $\begin{array}{l}\text { Positive } \\
\text { impacts }\end{array}$ & Rank & $\begin{array}{c}\text { Negative } \\
\text { impacts }\end{array}$ & Rank & $\begin{array}{c}\text { Overall } \\
\text { Impacts }\end{array}$ & Rank \\
\hline Economic Impacts & $1.94(\mathrm{~A})$ & 1 & $2.34(\mathrm{~A})$ & 2 & $2.10(\mathrm{~A})$ & 1 \\
\hline Social-cultural Impacts & $2.04(\mathrm{~A})$ & 3 & $2.65(\mathrm{~N})$ & 3 & $2.24(\mathrm{~A})$ & 2 \\
\hline Environmental Impacts & $1.98(\mathrm{~A})$ & 2 & $2.31(\mathrm{~A})$ & 1 & $2.44(\mathrm{~A})$ & 3 \\
\hline Overall impacts of tourism & \multicolumn{2}{|l|}{$1.99(\mathrm{~A})$} & \multicolumn{2}{|c|}{$2.40(\mathrm{~A})$} & \multicolumn{2}{|c|}{$2.18(\mathrm{~A})$} \\
\hline
\end{tabular}

Attitudes towards Perceived Economic Impacts of Tourism Development: Based on the mean scores of each impact item (Table 2), students respondents tend to strongly agree that tourism has provided more desirable job opportunities and new business development opportunities for the community (mean=1.43) and has attracted more investment and spending for the Albanian people (mean=1.59) than other sectors. Further, the findings reveal the approval of the respondents on other positive economic impacts as: "visitors spending promote the development of the Albanian economy" (mean=1.67), "tourism has created a new ready market for our local products" (mean=1.82), "tourism has helped to improve the infrastructure facilities to the tourist areas" (mean=2), and "tourism makes possible the survival of peripheral attractive areas" (mean=2.16). Moreover, students' respondents believed that the tourism development had helped to increase both national government revenues (mean=2.02) and local government revenues (mean=2.16). However, their attitude became neutral concerning the economic impact "Residents revenue has increased because of tourism" (mean=2.63) which means that students nullify it as positive economic impact of tourism in Albania. Further findings on the perceived negative economic impacts of tourism clarify their attitude in this aspect. Therefore, students agreed strongly that tourism creates more seasonal job opportunities (mean=1.73). Moreover, they believed that work in tourism is paid less (mean=2.06) than in other sectors, that the development of tourism has dramatically increased construction costs and land prices in tourism areas (mean=2.1), that tourist industry in non-urban tourist areas has employed more people from urban areas than local residents (mean=2.49), and that the cost of living of residents is increased by tourism (mean=2.53). However, they kept a conservative attitude towards the possibility of leaving out the majority of the money earned from tourism (mean=3.13). The authors believe that this attitude comes from the fact that the majority of tourism businesses in Albania are local SMEs.

Attitudes towards Perceived Social-Cultural Impacts of Tourism Development: With regard to social-cultural impacts of tourism development in Albania (Table 3), students have more positive perceptions (mean=1.98) than negative ones. According to the survey findings, students believed strongly that tourism has provided an incentive for the restoration of historical and traditional buildings in Albania (mean=1.54). That's why, it is not particularly surprising about the finding that there are favorable perceptions towards social-cultural aspects of tourism, in that that tourism has increased good understanding and cultural exchange between people (mean=1.85), pride of residents for their country (mean=1.89), the image of the country in the eyes of others (mean=1.90), educational opportunities (mean=2.17) and cultural events (mean=2.06), entertainment and recreational opportunities (mean=2.19), presence and quality of public service (mean=2.30) for local people, the possibilities of not abandonment from residents of the remote peripheral areas (mean=2.18), and the possibilities of the economic power of women due to increased number of jobs created for women by tourism (mean=2.33). Recognizing the fact that survey population is composed of young students might lead to a more favorable perception towards the positive social-cultural impacts. However, the data revealed that tourism has also provided some negative, social-cultural impacts such as growth of traffic accidents in summer tourist season (2.17), imitation of the behavior and life style of the tourists (mean=2.58). Moreover, they revealed that the survey students kept a conservative attitude towards other social-cultural impacts such as the possible changes in the style and forms of traditional arts and crafts due to tourism (mean=2.61), the possibility of cash benefits from tourism by a small group of people only (mean=2.66), and an increase in social problems such as crime, drug use, prostitution, alcoholism in the community by tourism (mean=3.25).

Attitudes towards Perceived Environmental Impacts of Tourism Development: Findings about environmental impacts of tourism development in Albania (Table 4) show that the most favored impact item by students is "tourism increases attention to regulatory measures for the management and maintenance of the environment in the tourism area" (mean=1.78). Also, the students felt that tourism provides increased awareness and appreciation of environment (mean=1.82), an incentive for the protection and conservation of environment (mean=1.94) and a higher standard of roads and other public facilities than they would be otherwise (2.38). On the other hand, further data disclosed that regulatory measures designed for the management and maintenance of the environment in the tourism area were not always translated into practice. The following findings confirm this with the level of acceptance by students on existence of negative environmental impacts as: The informal and not suitable construction of tourist facilities is destroying the 
natural environment (mean=1.7), the noise level in tourism areas has increased by tourism during summertime (mean=1.8), tourism has increased the traffic congestion in/to the tourist area during summer season (1.84), tourism has begun to transform some tourist areas in overcrowded urban territory (2.1), tourist activities are causing the migration/the extinction of many species of fauna (mean=2,26), visitors' litter have reduced the attractiveness of landscapes (mean=2.44), tourism is responsible for water pollution in rivers, lakes and seas because of the discharge of untreated sewage from tourist facilities (mean=). However, their attitude became neutral for other environmental impacts as "tourism development is responsible for the forest destruction in or round the tourist area" (mean=2.73) and "tourism development is responsible for the limitation of power and drinking water at some areas surrounding tourist spots during summertime" (mean=3.38) which means that students nullify these impacts as negative environmental impacts of tourism development in Albania.

Respondents' suggestions for further tourism development in Albania: The findings of the survey show that the most expressed suggestion of the students concerning tourism development for sustainable future was the composition of the long-term strategy for the sustainable tourism development in Albania (mean=4.14) 2 and the increase of cooperation between the private sector, public sector and the community in the planning and management of tourism (mean=4.28). This means that the tourism development in Albania should be designed and controlled by all stakeholders of tourism in order to minimize the negative tourism impacts and enlarge positive ones. Besides, new ways should be proposed in this process to improve the future of tourism in order that all stakeholders profit from sustainable tourism development. Decrease of tourism attractiveness in the environment of some areas in Albania has led the students to make some suggestions as: the need for the physical and integrated planning of tourist areas in accordance with their natural and historic character (mean=4.67); the need for the further improvement (mean=5.35) of road infrastructure and tourism signage to and in tourist areas, public support facilities (as provision of parking, electricity, water and telecommunication, the public and green spaces, waste and sewage management); as well as the need for resolving the problem on the legal land ownership of and legal construction in tourist areas for successful urban planning, safe and competitive investments, and sustainable future of tourism in those areas (mean=7.69). The sixth most expressed suggestion concerning further tourism development was more orientation of tourism towards alternative forms, such as cultural tourism, ecotourism, agro tourism, cycle tourism, and the development of thermal spas (mean=8.35). With this suggestion, they see the need to develop more sustainable forms of tourism, as well as to target specific international markets in order to diversify tourism product of Albania from the neighboring competitive countries, successfully profiled in $3 S$ tourism. Moreover, they have expressed the suggestion that there is a necessity of improvement and intensification of promotion to make possible the further penetration of Albania in the western tourist market (mean=8.86). Besides, to increase the positive impacts of tourism and reduce the negative ones, students suggested as necessary the effective control of tourism development through the implementation of laws, regulatory measures, land use plans, and standards related to tourism activity (mean=8.98). In order to achieve sustainable tourism development, students considered also reducing the seasonality of tourism development in Albania as of a special importance (mean=9). They understand that the process of stimulating tourism demand of off-peak season would increase revenue from tourism while putting less pressure on the environment and community in peak season. As the future managers of tourism, survey students understand the importance of tourism human resources as the key basis of quality tourism offer. Therefore they suggested improving the building process of professional capacity in the tourism sector (9.63). To increase further the level of Albania's integration in the global tourism market, the students considered promotion of Foreign Direct Investment in the development of tourist resorts of a special significance (mean=9.84). Since the tourism in Albania is already in early stages of its development, to promote the mobilization of investment in tourism, students also suggested the creation of a supportive climate of tourism businesses leading to cost reduction of doing business (mean=9.98.). It may be necessary to promote investment in mountainous areas tourism through the creation of fiscal incentives for business investors, to provide tourist services with competitive prices comparing European ones, through reducing value added tax, and promoting the integration of sustainable tourism practices in tourism business activity, which lead finally in reduction of their operation cost. At the end, students have also asked the definition of an indicator system for monitoring sustainable tourism development and the creation of an efficient system of collecting and disseminating information on tourism's development (mean=10.98). Thus, students understand that the efforts to develop strategies for sustainable tourism without sufficient management information would reduce the process of the aspiration towards it.

\section{Conclusions}

\footnotetext{
2 the smaller value of the mean shows a greater priority of strategy
} 
Taking into consideration the outcomes of this research, one can conclude that tourism development in Albania has been associated with its costs and benefits. Despite that, findings from the main component analysis showed that Albanian people has received more benefits than costs from the tourism development. The last brought more economic benefits increasing the employment and business opportunities and improving local infrastructure, growing governmental revenue as well.

However, greater environmental costs were major concerns as they had evidenced negative impacts. Although the tourism industry had become the basis of economic growth in Albania, students remained careful about tourism development. Their suggestions aimed to enlarge tourism benefits with a parallel effort to reduce the consequences deprived by tourism, in order to orient tourism development in a more sustainable manner.

\section{References}

Boyle, R. A., (2012), An Overview Of Education For Australia: The Tourism Higher Education Context: Sustainable Education in Travel and Tourism. Retrieved from: http://www.istte.org/2012Conf.pdf

Dibra, M., \& Oelfke, T., (2011): "Integration of the Sustainable Tourism Concept within the Higher Education Curriculum: An Albanian Case Study", Second International Conference on "Challenges of Sustainable Tourism Development 2011", Shkoder/Albania

Dibra, M., Dhora, R., \& Dibra, Xh., (2012), "Preserving Local Character for Sustainable Tourism Development: National Park of Theth as a Case study", The first ICAUD, Tirana-Albania. Retrieved from: http://icaud.epoka.edu.al/2012/res/1_ICAUD_Papers/ 1ICAUD2012_Mirjam_Dibra_RDhora_XhDibra.pdf

INSTAT, (2012), Statistical Bülletin 2012. Albania. Retrieved from: http://www.instat.gov.al/media/195035/statistika_4_2012_.pdf

Junyent, M., (2007), "Network: Greening the Curriculum of Higher Education, in: UNESCO Education Sector. "Good Practices in Teacher Education Institutions". Good Practices N¹. Retrieved from: http://unesdoc.unesco.org/images/ 0015/001524/152452eo.pdf

Middleton, V.T.C. \& Hawkins, R., (1998), "Sustainable Tourism: A Marketing Perspective", Oxford, Butterworth-Heinemann.

MTKRS,(2008), Strategjia Sektoriale e Turizmit ne Shqiperi 2007 - 2013. Retrieved from: http://www.mtkrs.gov.al/web/pub/ strategjia_sektoriale_e_turizmit_2007_2013_me_vkm_qershor_2008_5_1.pdf

MTKRS, (2003), Strategjia e zhvillimit të turizmit në Shqiperi deri ne vitin 2012. Retrieved from: http://www.mtkrs.gov.al/

Pakdeepinit, P., (2007): A Model for Sustainable Tourism Development In Kwan Phayao Lake Rim Communities. Retrieved from: http://www.thapra.lib.su.ac.th/objects/thesis/fulltext/thapra/Prakobsiri_Pakdeepinit_Doctor/Fulltext.pdf

Sharpley, R., (2004), Tourism: A vehicle for development? Tourism and Development. Chanel View Publications, England

Swarbrooke, J., (2002), "Sustainable Tourism Management", CABI Publishing. London.

Tilbury, D., (2011), Education for Sustainable Development: An Expert Review of Processes and Learning, Paris, UNESCO. Retrieved from: http://unesdoc.unesco.org/images/0019/001914/191442e.pdf

UNEP \& UNWTO, (2005), Making Tourism More Sustainable - A Guide for Policy Makers, p.11-12 http://www.unep.fr/shared/publications/pdf/DTIX0592xPA-TourismPolicyEN.pdf

UNESCO, (2007), "The UN Decade of Education for Sustainable Development (DESD 2005-2014)" , Retrieved from: http://unesdoc.unesco.org/images/0015/001540/154093e.pdf

UNESCO (2002). Education for Sustainability, From Rio to Johannesburg: Lessons learnt from a Decade of Commitment, Paris. Retrieved from: http://unesdoc.unesco.org/images/0012/001271/127100e.pdf

UNESCO (2005). United Nations Decade of Education for Sustainable Development (2005-2014): International Implementation Scheme, Paris. Retrieved from: http://unesdoc.unesco.org/images/0014/001486/148654e.pdf

UNESCO, (2009), "World Conference on Education for Sustainable Development", Bonn, Germany. Retrieved from: http://www.esdworld-conference 2009.org/fileadmin/download/ESD2009ProceedingsEnglishFINAL.pdf

UNWTO, (January, 2013), World Tourism Barometer. Volume 11, , Retrieved from: http://dtxtq4w60xqpw.cloudfront.net/sites/all/ files/pdf/unwto_barom13_01_jan_excerpt_0.pdf

UNWTO, (2011), Tourism towards 2030 - Global Overview. Retrieved from: http://www.wise.co.th/wise/Knowledge_Bank/References/ Tourism/UNWTO_Tourism_Toward_2030.pdf

Weaver, D., (2006), "Sustainable Tourism: Theory and Practice". Elsevier Butterworth-Heinemann, England.

\section{Annexes: Data Analyzing Tables}


Table 2: Students' Perception towards Economic Impacts of Tourism in Albania

\begin{tabular}{|c|l|c|c|c|}
\hline Nr. & \multicolumn{1}{|c|}{ Questions } & Mean & $\begin{array}{c}\text { Likert } \\
\text { scale }\end{array}$ & $\begin{array}{c}\text { Std. } \\
\text { Dev. }\end{array}$ \\
\hline A. & Positive economic impacts of tourism & 1.94 & $\mathrm{~A}$ & \\
\hline 1 & $\begin{array}{l}\text { Tourism provides more desirable job opportunities and new business } \\
\text { development opportunities for the community. }\end{array}$ & 1.43 & $\mathrm{SA}$ & 0.58 \\
\hline 2 & Tourism attracts more investment and spending & 1.59 & $\mathrm{SA}$ & 0.61 \\
\hline 3 & Visitors spending are injection for the Albanian economy. & 1.67 & $\mathrm{~A}$ & 0.66 \\
\hline 4 & Tourism creates a new ready market for our local products & 1.82 & $\mathrm{~A}$ & 0.78 \\
\hline 5 & $\begin{array}{l}\text { Investments in the public infrastructure and other facilities have } \\
\text { increased by tourism }\end{array}$ & 2 & $\mathrm{~A}$ & 0.82 \\
\hline 6 & The national government revenue has increased by growth of tourism & 2.02 & $\mathrm{~A}$ & 1 \\
\hline 7 & Tourism has increased tax revenues for local governments & 2.16 & $\mathrm{~A}$ & 0.83 \\
\hline 8 & Tourism makes possible the survival of peripheral areas attractive & 2.16 & $\mathrm{~A}$ & 0.96 \\
\hline 9 & Revenue of residents has increased because of tourism & 2.63 & $\mathrm{~N}$ & 1.03 \\
\hline & Negative economic impacts of tourism & 2.34 & $\mathrm{~A}$ & \\
\hline 10 & Tourism creates more job opportunities seasonal & 1.73 & $\mathrm{SA}$ & 0.86 \\
\hline 11 & Work in tourism paid less. & 2.06 & $\mathrm{~A}$ & 1.19 \\
\hline 12 & $\begin{array}{l}\text { Development of tourism has dramatically increased construction costs } \\
\text { and land prices in tourism areas }\end{array}$ & 2.1 & $\mathrm{~A}$ & 0.80 \\
\hline 13 & $\begin{array}{l}\text { The tourist industry in non-urban tourist areas has employed more } \\
\text { people from urban areas than local residents }\end{array}$ & 2.49 & $\mathrm{~A}$ & 0.82 \\
\hline 14 & The cost of living of residents is increasing by tourism & 2.53 & $\mathrm{~A}$ & 1.02 \\
\hline 15 & $\begin{array}{l}\text { Most of the money earned from tourism development in our country } \\
\text { ends out of Albania }\end{array}$ & 3.13 & $\mathrm{~N}$ & 0.98 \\
\hline & Total economic impacts of tourism & 2.10 & $\mathrm{~A}$ & \\
\hline
\end{tabular}

Table 3: Students' Perception towards Social-Cultural Impacts of Tourism in Albania

\begin{tabular}{|c|l|c|c|c|}
\hline Nr. & \multicolumn{1}{|c|}{ Questions } & Mean & $\begin{array}{c}\text { Likert } \\
\text { Scale }\end{array}$ & $\begin{array}{c}\text { Std. } \\
\text { Dev }\end{array}$ \\
\hline & Total positive social-cultural impacts of tourism & 2.03 & $\mathrm{~A}$ & \\
\hline 1 & $\begin{array}{l}\text { Tourism has provided an incentive for the restoration of historical and } \\
\text { traditional buildings }\end{array}$ & 1.54 & $\mathrm{SA}$ & 0.68 \\
\hline 2 & $\begin{array}{l}\text { Meeting tourists has increased good understanding and cultural } \\
\text { exchange between people. }\end{array}$ & 1.85 & $\mathrm{~A}$ & 0.62 \\
\hline 3 & $\begin{array}{l}\text { Pride of residents for natural and historic-cultural heritage of their country } \\
\text { has increased due to tourism }\end{array}$ & 1.89 & $\mathrm{~A}$ & 0.89 \\
\hline 4 & The image of the country in the eyes of others has increased & 1.90 & $\mathrm{~A}$ & 0.97 \\
\hline 5 & Tourism is encouraging more cultural events for the local residents & 2.06 & $\mathrm{~A}$ & 1 \\
\hline 6 & There are more educational opportunities for locals due to tourism & 2.17 & $\mathrm{~A}$ & 0.97 \\
\hline 7 & Development of tourism reduces depopulation of peripheral tourist areas & 2.18 & $\mathrm{~A}$ & 0.88 \\
\hline 8 & $\begin{array}{l}\text { Entertainment and recreational opportunities for local people have } \\
\text { increased by tourism }\end{array}$ & 2.19 & $\mathrm{~A}$ & 1.04 \\
\hline 9 & $\begin{array}{l}\text { Tourism has led to an increase of presence and quality of public service } \\
\text { for local people }\end{array}$ & 2.30 & $\mathrm{~A}$ & 1.02 \\
\hline 10 & $\begin{array}{l}\text { Women are gaining more economic power due to more created jobs for } \\
\text { women by tourism }\end{array}$ & 2.33 & $\mathrm{~A}$ & 0.97 \\
\hline & Total negative social-cultural impacts of tourism & $\mathbf{2 . 6 5}$ & $\mathrm{N}$ & \\
\hline 11 & Tourism growth in summertime increases traffic accidents & 2.17 & $\mathrm{~A}$ & 1.04 \\
\hline 12 & $\begin{array}{l}\text { Tourism encourages residents to imitate the behavior, live style of the } \\
\text { tourists }\end{array}$ & 2.58 & $\mathrm{~A}$ & 0.82 \\
\hline 13 & $\begin{array}{l}\text { The commercial demand of tourists causes changes in the style and } \\
\text { forms of traditional arts and crafts }\end{array}$ & 2.61 & $\mathrm{~N}$ & 0.97 \\
\hline 14 & Cash income from tourism goes in benefit of a small group of people & 2.66 & $\mathrm{~N}$ & 1.30 \\
\hline
\end{tabular}




\begin{tabular}{|c|l|c|c|c|}
\hline 15 & $\begin{array}{l}\text { Tourism has increased social problems such as crime, drug use, } \\
\text { prostitution, alcoholism in the community }\end{array}$ & 3.25 & $\mathrm{~N}$ & 0.93 \\
\hline & Total social-cultural impacts of tourism & $\mathbf{2 . 2 4}$ & $\mathrm{A}$ & \\
\hline
\end{tabular}

Table 4: Students' Perception towards Environmental Impacts of Tourism in Albania

\begin{tabular}{|c|l|c|c|c|}
\hline Nr. & \multicolumn{1}{|c|}{ Questions } & Mean & $\begin{array}{c}\text { Likert } \\
\text { Scale }\end{array}$ & $\begin{array}{c}\text { Std. } \\
\text { Dev. }\end{array}$ \\
\hline & Total positive environmental impacts of tourism & 1.98 & $\mathrm{~A}$ & \\
\hline 1 & $\begin{array}{l}\text { Tourism adds attention to regulatory measures for the management and } \\
\text { maintenance of the environment in the area }\end{array}$ & 1.78 & $\mathrm{SA}$ & 0.74 \\
\hline 2 & Tourism helps to increase awareness and appreciation of environment & 1.82 & $\mathrm{~A}$ & 0.92 \\
\hline 3 & $\begin{array}{l}\text { Tourism provides an incentive for the protection and conservation of } \\
\text { natural resources }\end{array}$ & 1.94 & $\mathrm{~A}$ & 1.08 \\
\hline 4 & $\begin{array}{l}\text { Due to tourism roads and other public facilities are kept at a higher } \\
\text { standard than they would be otherwise }\end{array}$ & 2.38 & $\mathrm{~A}$ & 1.21 \\
\hline 5 & $\begin{array}{l}\text { Total negative environmental impacts of tourism } \\
\text { the natural environment }\end{array}$ & 2.31 & $\mathrm{~A}$ & \\
\hline 6 & Noise level in tourism areas has increased by tourism during summertime & 1.80 & $\mathrm{SA}$ & 0.67 \\
\hline 7 & $\begin{array}{l}\text { Tourism increases the traffic congestion in/to the tourist area during } \\
\text { summer season }\end{array}$ & 1.84 & $\mathrm{~A}$ & 0.68 \\
\hline 8 & $\begin{array}{l}\text { Tourism has began to transform some tourist areas in overcrowded urban } \\
\text { territory }\end{array}$ & 2.1 & $\mathrm{~A}$ & 0.84 \\
\hline 9 & $\begin{array}{l}\text { Tourist activities are causing the migration/the extinction of many species } \\
\text { of fauna }\end{array}$ & 2.26 & $\mathrm{~A}$ & 0.92 \\
\hline 10 & Visitors' litter have reduced the attractiveness of landscapes & 2.44 & $\mathrm{~A}$ & 0.95 \\
\hline 11 & $\begin{array}{l}\text { Tourism is responsible for water pollution in rivers, lakes and seas of our } \\
\text { country of the discharge of untreated sewage from tourist facilities }\end{array}$ & 2.54 & $\mathrm{~A}$ & 1.22 \\
\hline 12 & $\begin{array}{l}\text { Tourism development is responsible for the forests' destruction in or round } \\
\text { the tourist area }\end{array}$ & 2.73 & $\mathrm{~N}$ & 1.20 \\
\hline 13 & $\begin{array}{l}\text { Tourism development is responsible for the limitation of energy, water at } \\
\text { some areas surrounding tourist area during summertime }\end{array}$ & 3.38 & $\mathrm{~N}$ & 1.12 \\
\hline & Total environmental impacts of tourism & 2.20 & $\mathrm{~A}$ & \\
\hline
\end{tabular}

